\title{
Letters
}

\section{NO DETECTION OF MACROPHAGE ERYTHRO- POIETIN PRODUCTION IN BONE MARROW FROM RHEUMATOID ARTHRITIS PATIENTS WITH AND WITHOUT ANAEMIA AND CON- TROLS}

\section{To the Editor}

Anaemia is a common extraarticular manifestation of rheumatoid arthritis (RA). Apart from deficiencies of iron, vitamin $\mathrm{B} 12$ and folic acid and adverse antirheumatic drug reactions, the anaemia of chronic disease (ACD) is the most frequent cause of anaemia in RA (1). Much research has been carried out to examine its pathophysiology, such as altered iron metabolism $(2,3)$ and cytokines - like interleukin 1 and tumour necrosis factor, which may suppress erythropoiesis (4). Another mechanism underlying ACD in RA might be an insufficient erythropoietin (Epo) responsiveness to the anaemia $(1,5)$ or decreased erythroblast-Epo sensitivity based on findings that Epo-induced erythroid growth is reduced in RA complicated by ACD (6). Rich reported that macrophages in bone marrow are able to produce and release Epo depending on local $\mathrm{pH}$ and oxygen tension (7) and exhibit Epo gene expression (8). These observations prompted us to investigate whether Epo production is detectable in bone marrow derived from RA patients and controls and whether Epo production by marrow macrophages and its metabolism is altered in ACD.

Serum and bone marrow were obtained from 5 nonanaemic RA patients, 5 RA patients with ACD (based on normal to increased bone marrow iron stores and the exclusion of other causes of anaemia) and 4 controls (bone marrow transplant donors), after they gave written informed consent. Mean age of

Table I : Parameters of erythropoiesis, $R A$ activity, iron status and marrow Epo production $R A$ patients with $A C D$ and without anaemia

\begin{tabular}{lccc}
\hline & $\begin{array}{c}\text { ACD } \\
(\mathrm{n}=5)\end{array}$ & $\begin{array}{c}\text { Nonanemics } \\
(\mathrm{n}=5)\end{array}$ & $\begin{array}{c}\text { Controls } \\
(\mathrm{n}=4)\end{array}$ \\
\hline $\mathrm{Hb}$ & $10.8^{* *}$ & 12.7 & 13.0 \\
$(\mathrm{~g} /)$ & $(9.2-11.1)$ & $(11.9-14.0)$ & $(12.4-13.2)$ \\
$\mathrm{Ht}$ & $0.33^{* * *}$ & 0.37 & 0.40 \\
$(1 / 1)$ & $(0.28-0.35)$ & $(0.36-0.41)$ & $(0.37-0.40)$ \\
$\mathrm{ESR}$ & $87^{* *}$ & $36^{*}$ & 14 \\
$(\mathrm{~mm} / \mathrm{h})$ & $(52-92)$ & $(21-65)$ & $(12-16)$ \\
$\mathrm{CRP}$ & $31^{* *}$ & $22^{*}$ & 3 \\
$(\mathrm{mg} / 1)$ & $(11-74)$ & $(2-54)$ & $(2-4)$ \\
$\mathrm{Ferritin}$ & $121^{* *}$ & $53^{*}$ & 22 \\
$(\mathrm{ug} / 1)$ & $(89-432)$ & $(10-326)$ & $(10-34)$ \\
$\mathrm{EPO}$ & $<0.1$ & $<0.1$ & $<0.1$ \\
$(\mathrm{mU} / \mathrm{ml})$ & -- & - & -- \\
$\mathrm{EPO}++$ & 410 & 470 & 430 \\
$(\mathrm{mU} / \mathrm{ml})$ & $(380-470)$ & $(360-475)$ & $(420-475)$ \\
\hline
\end{tabular}

Data are expressed as median (range); ${ }^{*} \mathrm{p}<0.10 ;{ }^{* *} \mathrm{p}<0.05$ compared to controls; ++ Epo concentration after addition of $1 \mathrm{U} / \mathrm{ml}$ Epo to the medium. the RA patients was $59( \pm 6)$ years and of the controls $32( \pm 4)$ years. None of the RA subjects were treated with steroids or cytostatic drugs. After Ficoll separation, one million mononuclear cells were added to a medium containing the usual substances for BFUe colony assessment (9), up to volume of $1 \mathrm{ml}$. It was then incubated for 48 hours at 37 degrees centigrade and $100 \%$ humidity in $5 \% \mathrm{CO}_{2}$. This procedure was repeated with the addition of $1 \mathrm{U} / \mathrm{ml}$ of Epo (Boehringer Vienna, Austria). The cell suspension was centrifuged and the supernatant was tested for Epo, using an ELISA Epo assay as recently developed (Bochringer Mannheim, W-Germany; lowest detection level $0.1 \mathrm{mU} / \mathrm{ml}$, reference values in serum $0.4-8.9$ $\mathrm{mU} / \mathrm{ml}$ ). The results are shown in Table I. No Epo could be detected in any of the marrow cultures of the three groups. After the addition of Epo to the cultures less than 50\% was recovered after 48 hours of culturing.

These observations may indicate that Epo production and/or release by marrow macrophages in culture is not detectable in the three groups studied here. The second experiment shows that recovery of Epo added to the cultures is less than $50 \%$, suggesting that Epo is metabolized, adhered to or incorporated into the marrow cells, which were washed away in these experiments. The Epo initially produced in the marrow cultures in the first experiment might have been below the detection limit or metabolized before measurement. Apparently net macrophage Epo production or release after 48 hours of culturing is undetectable in either group and Epo metabolism is similar in the three groups. Consequently, these preliminary data do not support the concept of altered marrow Epo production or metabolism by macrophages or other cells present in bone marrow as a cause of ACD in RA.

Acknowledgements: This study was supported by a grant from the Dutch League against Rheumatism and Boehringer Mannheim, West-Germany.

\section{G. VREUGDENHIL,} P.J.W. COPPENS*, B. LOWENBERG**, A.J.G. SWAAK***

Department of Internal Medicine, Division of Hematology, Sint Radboud University Hospital, Nijmegen ; * Department of Internal Medicine, Canisius Wilhelmina Hospital Nymegen; ** Department of Hematology, Dr. Daniel den Hoed Clinic and Dijkzigt University Hospital, Rotterdam; *** Department of Rheumatology, Dr. Daniel den Hoed Clinic, Rotterdam, The Netherlands.

\section{REFERENCES}

1. Vreugdenhil, G., Wognum, A.W., Van Eijk, H.G., Swaak, A.J.G. Anaemia in rheumatoid arthritis. The role of iron, vitamin B12 and folic acid deficiency and erythropoietin responsiveness. Ann Rheum Dis 1990 49, 93-98.

2. Beamish, M.R., Davis, A.G., Eakins, J.D., et al. The measurement of reticuloendothelial iron release using iron dextran. Br J Haematol 1971, 21, 617-622. 
3. Vreugdenhil, G., Kroos, M.L., Van Eijk, H.G., Lowenberg, B., Swaak, A.J.G. Impaired iron uptake and transferrin binding by erythroblasts in anaemia in rheumatoid arthritis. $\mathrm{Br} \mathbf{J}$ Rheumatol 1990, 29, 335-339.

4. Maury, C.P.J. Editorial. Anaemia in rheumatoid arthritis, Role of cytokines. Scand J Rheumatol 18, 3-5, 1989.

5. Vreugdenhil, G., Swaak, A.J.G. Review. The role of erythropoietin in the anaemia of chronic disease in rheumatoid arthritis. Clin Rheumatol, 1990, 9, 22-27.

6. Vreugdenhil, G., Lowenberg, B., Van Eijk, H.G., Swaak, A.J.G. Anaemia of chronic disease in rheumatoid arthritis. Raised serum interleukin- 6 and effects of IL- 6 and anti-IL- 6 on in vitro erythropoiesis. Rheumatol Int 1990, 10, 127-130.

7. Rich, I.N.A. role for the macrophage in normal hemopoiesis. II. Effect of varying physiological tensions on the release of hemopoietic growth factors from bone marrow derived macrophages in vitro. Exp Hematol 1986, 14, 746-751.

8. Rich, I.N. Hemopoietic regulation and the role of the macrophage in erythropoietic gene expression. Adv Exp Med Biol 1988, 241, 55-66.

9. Bot, F.J., Dorssers, L., Wagenmaker, G., Lowenberg, B. Stimulating spectrum of human recombinant multi-CSF(IL3) on human marrow precursors: importance of accessory cells. Blood 1988, 71, 1609-1614.

\section{HERPES SIMPLEX VIRUS ANTIGENS IN SERA OF PATIENTS WITH BEHCET'S DISEASE}

\section{To the Editor:}

In a recent study, it was reported that titres of IgG antibodies to herpes simplex virus type 1 (HSV-1) were significantly higher in the sera of patients with Behcet's disease (BD). Levels of IgG antibodies were significantly higher in patients with active disease than in patients with inactive disease. These results suggested some evidence for involvement of HSV-1 in the immunopathogenesis of BD (1). In the present study we investigate HSV antigens in the sera of patients with $\mathrm{BD}$.

Twenty patients (19 male, one female) with a mean age of $39 \pm 3$ (range 29-58) were studied. Disease duration was $6.8 \pm$ 1.9 (range 2-25). All patients fulfilled the diagnosis criteria proposed by the International Study Group for Behcet's dis- ease (2). Clinical manifestations were as follows: buccal aphthosis $(n=20)$ genital aphthosis $(n=17)$, necrotic pseudofolliculitis $(n=15)$, dermohypodermal lesions $(n=5)$ positive pathergic test $(\mathrm{n}=13)$ venous thrombosis $(\mathrm{n}=8)$, arthritis $(\mathrm{n}=7)$ central nervous system $(=3)$ arterial aneurysm $(\mathrm{n}=$ 2). The disease was active in 12 patients and inactive in 8. Antigens present in sera of BD patients at different stages were investigated using an ELISA technique. Monoclonal antibodies against HSV-1 and 2 were fixed on wells of polystyrene plates. 100 microliters of sera were incubated pure and at $1: 10$ for one hour at $37^{\circ} \mathrm{C}$. After washing, 100 microliters of anti HSV monoclonal antibody was added (1:50 for one hour). After washing, phosphatase alcaline conjugate was added for 1 hour (100 microliters). Finally, 100 microliters of phosphatase alcaline substrate were used for $20 \mathrm{~min}$.

Positive controls used were HSV-1 and 2 strains purified in ultracentrifugation gradient sucrose and ultrasonicated. Negative controls were PBS. Positive controls had a high optical density at $405 \mathrm{~nm}(>0.6)$. Negative controls were always $<0.15$. On the 20 patients tested, none had positive results by this assay.

Reactivation of the BD does not seem to be associated with liberation of HSV particles in the sera but with rise of antibodies against HSV as previously described.

\section{HAMZA,}

A. SLIM*

Service de Rhumatologie Hôpital la Rabta. Tunis ; *Laboratoire de Bacteriologie et de Virologie, Hôpital Charles Nicolle, Tunis, Tunisie.

\section{REFERENCES}

1. Hamza, M., Elleuch, M., Slim, A., Hamzaoui, K., Ayed, K. Antibodies to herpes simplex virus in patients with Behcet's disease. Clin Rheumatol 1990, 9, 498-500.

2. International study group for Behcet's disease. Criteria for diagnosis of Behcet's disease. Lancet 1990, 335, 1078-1080. 